\title{
OPTIMALISASI PEMANFAATAN LAHAN PEKARANGAN SEBAGAI SUMBER PANGAN
}

\author{
Nomi Noviani siregar ${ }^{1)}$, Sri Wahyuni' ${ }^{2)}$ \\ Universitas Muslim Nusantara Al-Wasliyah \\ Jalan Garu II No. 93, Medan Amplas, SitirejoIII, kota Medan Sumatera Utara \\ Email: noviani_nomi@yahoo.com
}

\begin{abstract}
ABSTRAK
Pada mulanya bertanam sayur di pekarangan hanya dimaksudkan untuk memenuhi kebutuhan gizi keluarga dengan memanfaatkan halaman rumah yang tersisa, sehingga kegiatan ini banyak dikembangkan di pedesaan. Namun saat ini budaya bertanam sayuran di pekarangan ternyata juga disukai kalangan ibu rumah tangga di daerah perkotaan. Daerah perkotaan ada yang sama sekali tidak memiliki lahan pekarangan maka bertanam sayuran dapat dilakukan di dalam pot atau dilakukan secara vertikultur. Dalam pemanfaatan pekarangan menjadi taman sayura sapek budidaya dari tanaman tetap harus diperhatiakan. Dengan demikian tujuan dari pemanfaatan pekarangan berapa pun luasannya akan memberikan hasil yang optimal.
\end{abstract}

Kata Kunci: Optimalisasi, Pekarangan, Produktifitas

\begin{abstract}
Initially planted vegetables in the yard is only intended to meet the nutritional needs of families by utilizing the remaining home pages, so this activity is widely developed in rural areas. But now the culture of growing vegetables in the yard was also favored among housewives in urban areas. There are urban areas that do not have a yard land then vegetables can be planted in pots or done vertikultur. In the utilization of the yard into the garden sayura sapek cultivation of the plant should still diperhatiakan. Thus the purpose of utilizing the yard regardless of its extent will provide optimal results.
\end{abstract}

Keywords: Optimization, Yard, Productivity 


\section{PENDAhuluan}

\subsection{Latar Belakang}

Pekarangan adalah lahan terbuka yang terdapat di sekitar rumah tinggal. Lahan ini jika dipelihara dengan baik akan memberikan lingkungan yang menarik nyaman dan sehat serta menyenangkan sehingga membuat kita betah tinggal di rumah.Pekarangan rumah kita dapat kita manfaatkan sesuai dengan selera dan keinginan kita. Misalnya dengan menanam tanaman produktif seperti tanaman hias, buah, sayuran, rempahrempah dan obat-obatan.

\subsection{Tujuan}

Dengan menanam tanaman produktif di pekarangan akan memberi keuntungan ganda, salah satunya adalah kepuasan jasmani dan rohani. Bahkan jika jumlahnya cukup banyak bisa dijual yang akan memberikan keuntungan ekonomis. Martha Stewart juga melakukan usaha berkebun sayuran di pekarangan yang terdapat di belakang rumahnya di kawasan Bedford, Cantitoe Corners sejak tahun 2001.

Selain dari manfaat estetis dan produktif dari taman sayur ada manfaat lain yang bisa kita peroleh. Dengan taman sayur di pekarangan kita ikut mendukung gaya hidup hijau yang merupakan suatu usaha untuk mengatasi laju pemanasan global yang bisa kita mulai dari rumah kita.

\subsection{Pendekatan pemecahan masalah \\ Dengan pemnfaatan} pekarangan mengeluarkan biaya sedikit didalam melaksanakan penanaman di dalam pekarangan tersebut akan dapat hasil yang lebih banyak, sehingga dengan usaha memanfaatkan tanah pekarangan itu berarti keluarga bersangkutan telah melaksanakan prinsip-prinsip ekonomi didalam meningkatan pendapatan. Untuk dapat menunjang suksesnya tanaman- tanaman di dalam pekarangan tersebut perlu pula melakukan pemupukan dengan pupuk kandang, kompas yang diperoleh tanpa membeli atau diperoleh dari dalam pekarangan itu sendiri.Jika ada bibit penyakit pada tanaman didalam pekarangan tersebut disarankan supaya sebaiknya didalam melakukan pemberantasan jangan memakai obatobatan yang untuk memperolehnya harus mengeluarkan uang tetapi sebaiknya diberantas dengan membakar sampah-sampah sedikit demi sedikit.

\section{Metode Pelaksanaan}

1. Persiapan Media Tanam, Tahap ini merupakan tahap awal dalam berkebun.

2. Menentukan Jenis Tanaman, Pilihlah jenis tanaman yang bermanfaat bagi keperluan rumah tangga baik untuk obat atau kesehatan dan keperluan dapur serta pelengkap gizi.

3. Tata Letak Tanaman, Pada prinsipnya semua tanaman memerlukan sinar matahari yang cukup sepanjang hari. Tempatkan jenis-jenis yang berukuran kecil mulai dari bagian Timur dan tempatkan jenis tanaman yang berukuran besar seperti buah-buahan di bagian sebelah Barat.

4. Pemeliharaan,Tahap pemeliharaan baik untuk lahan maupun tanaman merupakan 
hal yang harus selalu diperhatikan. Pemeliharaan tanaman meliputi beberapa aspek yang harus diperhatikan yaitu penyiangan, penyiraman, pemupukan serta pengendalian hama dan penyakit.

6. Pemanenan, Sayuran perdu yang dipetik daunnya sudah dapat dipetik hasilnya pada umur 35 - 40 hari. Namun berbeda denga bayam cabut dan kangkung darat dilakukan secara langsung dengan mencabut tanaman beserta akarnya. Jenis sayuran seperti kol, sawi, selada dipanen umur2- 3bulan.

7. Budidaya Organik, Budidaya tanaman di pekarangan sebaiknya dilakukan secara organik atau sesedikit mungkin menggunakan bahan kimia. melalui upaya tersebut bahan pangan yang dihasilkan lebih sehat.

8. pola tanam vertikal (tanam bersusun) Pola tanam vertikal merupakan usaha pertanian dengan memanfaatkan lahan semaksimal mungkin dengan memanfaatkan potensi ketinggian, sehingga tanaman yang diusahakan per satuan luas lebih banyak.

9. Tabulapot adalah menanam tanaman buah-buahan (bisa tanaman lainnya: bunga) di dalam pot.

\section{Hasil dan Pembahasan}

Dengan diadakan pengabdian kepada masyarakat tepatnya di Desa Doulu, dengan judul Optimalisasi Pemanfaatan Lahan Pekarangan
Sebagai Sumber Pangan, sesuai dengan judulnya masyarat di Desa Doulu sadar bahwa pekarangan mempunyai manfaat yang penting sebagai sumber tambahan pangan. Dengan memanfaatan lahan pekarangan secara efisien dan berkesinambumgam maka pengeluaran keluarga menjadi berkurang karena adanyapekarangan tersebut akan dapat hasil yang lebih banyak, sehingga dengan usaha memanfaatkan tanah pekarangan itu berarti keluarga bersangkutan telah melaksanakan prinsip-prinsip ekonomi didalam meningkatan pendapatan.

\section{Kesimpulan}

Pekarangan rumah berapa pun luasannya dapat dimanfaatkan secara optimal sehingga akan meningkatkan produktivitasnya. Pekarangan yang ditanami dengan sayuran memberikan kontribusi yang cukup besar pada usaha mencukupi kebutuhan gizi keluarga. Dalam pemanfaatan pekarangan dengan sayuran harus diperhatikan juga aspek budidaya dari sayuran yang ditanam

\section{Daftar Pustaka}

AndhikaJ.,2009. Pemanfaatan Lahan Pekarangan Secara Optimal.http://www.kulinet.co $\mathrm{m} /$ baca/pemanfaatan-lahanpekarangan-secara-

Anonim, 2009 Tips Green Living Sederhana

Mubyarto, 1998. Pengantar Ekonomi Pertanian, Lembaga Penelitian, Pedidikan dan Penerangan Ekonomi dan Sosial, Jakarta

Nazaruddin, 1999. Budidaya dan Pengaturan Panen Sayuran 
Dataran Rendah, Penebar Swadaya, Jakarta

Nugroho, H dan Novalinda, D, 2007. Usaha Sayuran Sehat di Dataran Rendah Balai Pengkajian Teknologi Pertanian, Jambi

Prawirokusumo, S, 1990. Ilmu Usahatani, BPFE, Yogyakarta

Rahardi, F, 2000. Agribisnis Tanaman Sayuran, Penerbit Swadaya, Jakarta Sumarjono, H, 2013. Berkebun 26 Jenis Tanaman Buah, Penebar Swadaya, Jakarta Soekartawi, 1995. Analisis Usahatani, UI-Pers

Williams, Uzo, Peregrine, 1993. Produksi Sayuran di Daerah Tropika, Gadjah Mada Press, Yogyakarta 